\title{
Exchange Rate Fluctuations and Sectoral Performance of the Nigerian Economy (1980- 2016)
}

\author{
Afolabi Adejumo \\ $\mathrm{PhD}$, Office of the Economic Adviser to the President, Abuja, Nigeria
}

\begin{abstract}
The structure of Nigerian economy has changed considerably over the years. The economy is classified into five interrelated sectors; the agriculture, Industry, construction, trade and services (CBN 2016). Some of these sectors have contributed to the national output and government revenue at different point in time. Different exchange rate regimes implemented in the country have had varying degrees of impact on the performance of the economic sectors. Depending on the foreign exchange component of inputs into the various sectors and the export earning potential of each sector, sectoral performance has shown high level of sensitivity to exchange rate fluctuations. Fluctuations in exchange rate affect the cost of production in the various sectors of the economy. It is, therefore, not surprising that exchange rate is among the most watched, analysed and government manipulated macroeconomic indicator as it plays a vital role in a country's level of trade, which is critical for every free market economy in the world. This paper is a review of the performance of the Nigerian economy in the light of the volatility of exchange rates in Nigeria.
\end{abstract}

Keywords: exchange rate fluctuations, sectoral performance, Nigerian economy

\section{Introduction}

The Nigerian economy is classified into five interrelated sectors; the agriculture, Industry, construction, trade and services (CBN 2016). Some of these sectors have contributed to the national output and government revenue at different point in time. Agricultural sector comprises four subsectors which cut across crop production, livestock, fisheries and forestry. The industry revolves around mining and quarrying, crude petroleum and manufacturing subsectors. Building and construction as well as the wholesale and retail trade have no subsector while the service sector has the highest number of subsectors. The service subsectors include transport, communication, utilities, hotel and restaurant, finance and insurance, real estate and business services; producers of government service as well as commercial, social and personal services. The outputs of these various sectors are affected by the movement 
in exchange rate. The manufacturing sub-sector's contribution to Nigerian economy is limited by the fluctuation in the exchange rate because most of the inputs used in production in this sub-sector are imported, therefore, the depreciation of Nigerian currency increases the cost of production in this sub-sector.

Prior to the 1970s, agriculture was the mainstay of the economy (Sertoğlu, et al., 2017), but following the discovery of oil in commercial quantity and the importance of oil in the international market, the petroleum industry has become the dominant industry in the economy for government revenue and foreign exchange earnings, making the link between the foreign exchange earnings, majorly the US dollars, and the performance of various sectors of the Nigeria economy strong. These strong interconnections, especially of those sectors that rely on foreign input and have weak capacity to generate foreign exchange needed, usually subject the economy to vulnerability in the inflow of foreign earnings and the price of crude oil in the international market.

Fluctuations in exchange rate affect the cost of production in the various sectors of the economy. It is, therefore, not surprising that exchange rate is among the most watched, analysed and government manipulated macroeconomic indicator as it plays a vital role in a country's level of trade, which is critical for every free market economy in the world. Most countries strive to moderate their domestic currency fluctuations by imposing restrictions on exchange rate movements (Ngerebo and Ibe, 2013). It is a key macroeconomic measure in the context of general reform programme and because of its importance, government takes active part in it determination. Specifically, it is important as the connection between the price systems of countries, as price in the allocation of real resources among tradable and non-tradable sectors, as a promoter or otherwise of imports and exports and as an instrument in the design of the balance of payment programme of countries.

\subsection{Trends in the Real Sector in Nigeria: Agriculture and Manufacturing}

\subsubsection{Agriculture sector}

In Nigeria, agricultural sector plays a crucial role in the economic development most especially before the discovery of oil in commercial quantity in the 1970's. This is because Nigeria is blessed with abundant land mass, which is fertile for agricultural purposes until many other countries (Federal Ministry of Agriculture and Rural Development, 2000). However, it still contributed significantly to the total output, the sector contributed more than $20 \%$ on average. It is seen in Figure 2.9 that the contribution of agriculture to gross domestic product rose gradually from $11.8 \%$ in 1981 to $29.5 \%$ in 1997 . This coincides with the period when the exchange rate was liberalized and relatively stable. More importantly, the significant increase in the share of agriculture to total output can be attributed to the government committed effort towards food security. 
In a bid to boost agricultural production during the 1980's the government introduced an incentive scheme by charged concessional interest rates on agricultural facilities till 1992. Also, during these periods, the agricultural sector was highlighted as one of the government priority sectors, as such, commercial banks were mandated to ensure that certain percentage of their deposits are issued out as a loan to the sector (Wahab, 2011). Furthermore, the growth rate of the sector output oscillates around $20 \%$. This reflects that the sector total output has been on the increasing path. This impressive feat can also be attributed to the Green Revolution Programme initiated by the government between 1980 and 1983. The programme was also aimed at ensuring that Nigeria is self-sufficiency in food production. The drive for a selfsufficient economy in food production led to the establishment of three Federal Universities of Agriculture in 1988 with the intention of boosting human capacity required for the advancement of the sector.

Post-2000, the share of the agricultural sector to GDP has been on the declining trend. It fell from $37.5 \%$ in 2002 to $26.3 \%$ in 2009 and then fell further to $20.2 \%$ in 2014 before increasing slightly to $21.2 \%$ in 2016 . The periods of decline in the share of agriculture to total GDP coincide with the periods of rising exchange rate and a slowdown in the growth rate of the sector output. While rising exchange rate might be associated with high cost of importation of farm implement, thus, increasing the overall cost of production. Other factors such as poor road network might account for the drop in the sector share in total output as well as the decline in the growth rate.

The agricultural sub-sector is one of the major sectors in the economy and a key determinant of long run economic development in Nigeria with the sub-sector contributing to development of an economy through production of goods, foreign exchange and exports (Ajudua et al., 2015). Just like the manufacturing sector, agricultural output also exhibits fluctuation. The average growth of agricultural output was 23.68 per cent in 1980s and 36.08 per cent in 1990s. The high growth witnessed in the 90s was due to direct involvement of Nigerian government in boosting the agricultural sub-sector with several large scale agricultural projects and programmes launched and established while concessionary interest rate structure was employed with direct cheap credit to the agricultural sub-sector (Ajudua et al., 2015).

The contribution of agriculture to the GDP fell between 2000 and 2009 as 18.56 per cent was reported on average during this period, from 2010, the rate has been fluctuating around 12 per cent. From the figure, it can be seen that despite various policies and schemes the government implemented during the democratic regime, much has not been achieved in terms of growth in output of the sub-sector. The policies include the National Economic Empowerment and Development Strategy (NEEDS) launched in 1999, the National, Special Programme on Food Security (NSPFS) launched in 2002, the Root and Tuber Expansion Programme (RTEP) 
launched in 2003, Seven-point Agenda of 2007, Transformation Agenda of 2011 and the Change Agenda of 2015.

Figure 10: Agriculture Sector Contribution to GDP

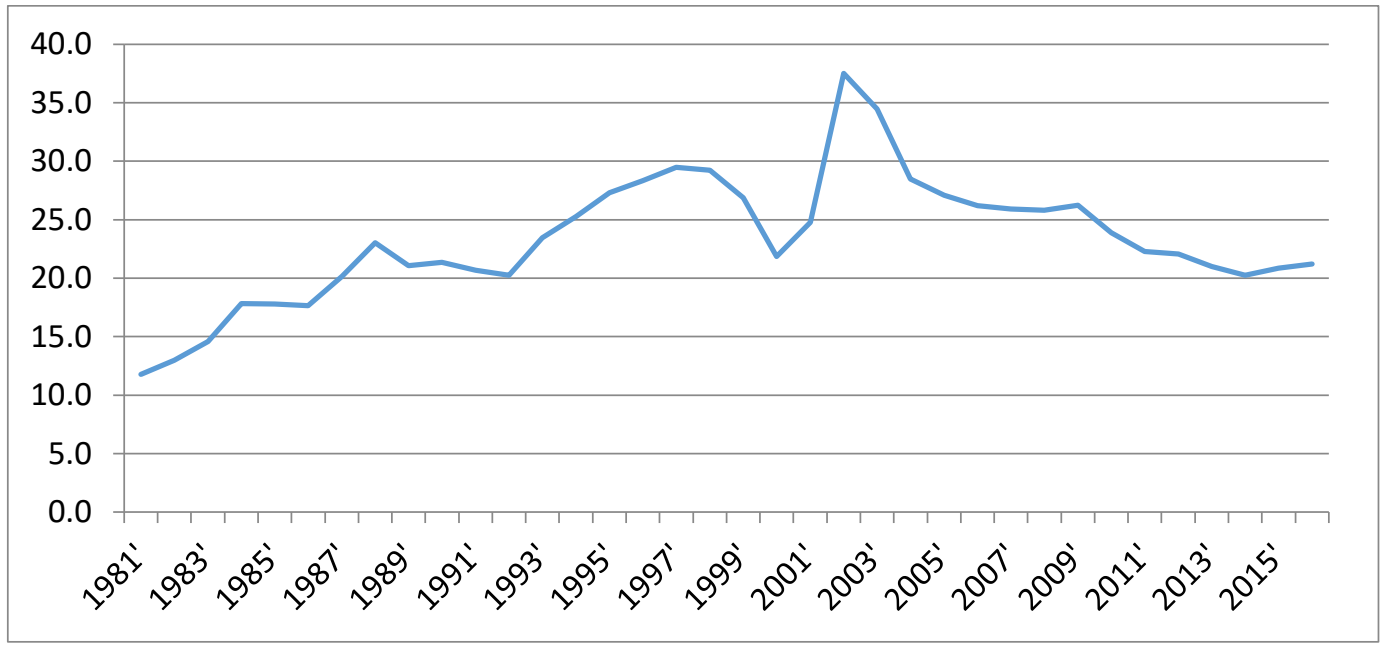

Source: CBN Statistical Bulletin, 2016

Figure 11: Agriculture Sector GDP Growth Rate (\%)

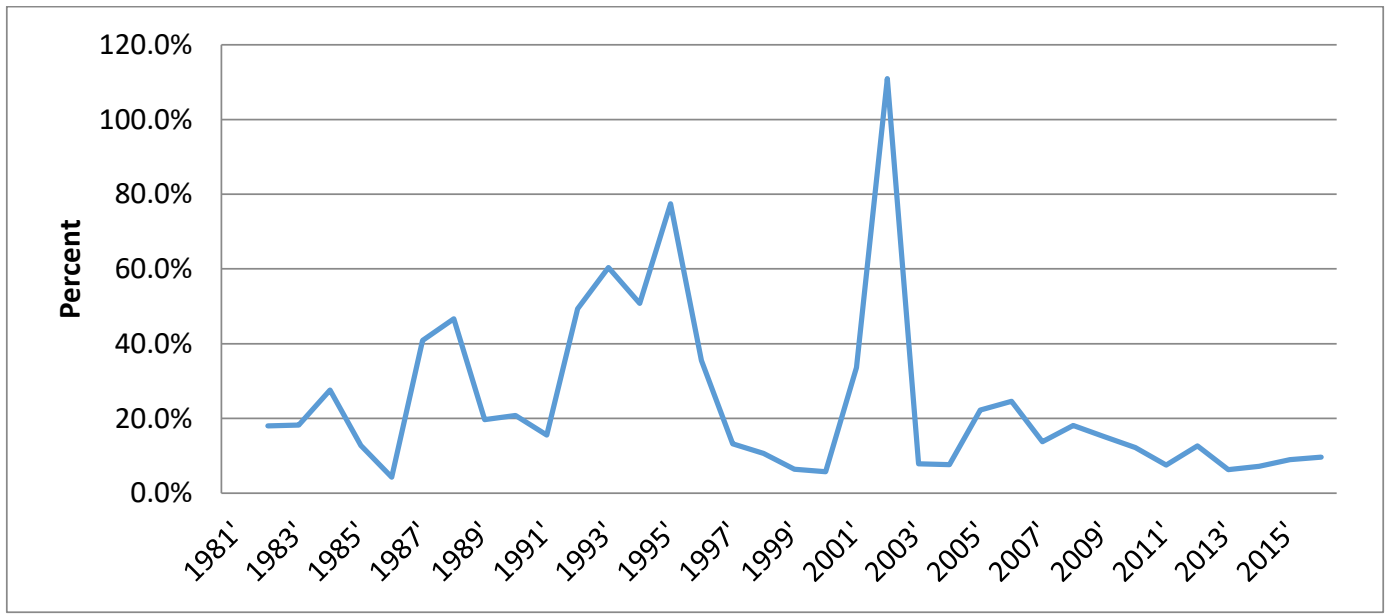

Source: CBN Statistical Bulletin, 2016

\subsection{Crude Oil \& Solid Minerals}

Apart from the agricultural sector, the crude oil and solid minerals sector is another primary sector in Nigeria. This sector shapes the economic and the political landscape in Nigeria. The significant of the sector can be traced to the discovery of crude oil in commercial quantities in early 1970 (Odularu, 2008). Figure 2.11 shows that on 
average crude oil and solid minerals contributed approximately $10 \%$ of the GDP. On a closer look, the performance of the sector experienced significant improvement during 1983 to 1991 . It rose gradually from $4.9 \%$ in 1983 to $16.5 \%$ in 1992 . The share of the sector in 1992 is less than three times of the sector share in 1983. The significant increase recorded can be associated with the depreciation of naira against the dollar after the liberalization of the exchange rate in the mid-1980's. This is because the depreciation of the exchange rate leads to an increase in the amount realized as proceeds from both crude oil and solid minerals.

The share of the sector in total output declined by $100 \%$, it fell from $16.5 \%$ in 1992 to $7.5 \%$ in 1994 . While the liberalization of the exchange rate leads to initial improvement of the sector, it later hurt the sector. This is because the weak nature of the country currency against the dollar increases the cost of operation as the sector is import dependent in term of equipment, thus reducing the capacity of the sector. The implication of this is that the crude oil and solid minerals sector output is affected more when compared to the other sectors of the economy that relied less on imported input, such as agriculture.

Due to the adverse consequence of the continuous depreciation of naira against the dollar after the liberalization of the exchange rate, the government then adopted fixed exchange rate management approach in 1994 and was ceased in 1997. During the period, the sector recorded the highest growth rate in 1995, while the share of the sector to GDP increased drastically till 1996 before it began to decrease, a trend similar to what was observed in term of the sector growth rate of the sector. Thus, it might be seen that the performance of the sector is partially influenced by the exchange rate.

Over the last one decade, the performance of the sector wasn't impressive. The share of crude oil and solid minerals declined from $14.8 \%$ in 2005 to $13.6 \%$ in 2008 and then fell further to $9.8 \%$ in 2009 . As the world economy recoveries from the $2007 / 2008$ financial crisis, the demand for crude oil increases, so also the share of the crude oil and solid minerals sector experienced an increased till 2011. After 2011, the contribution of the sector declined continually from $17.6 \%$ in 2011 to as low as 5.4 in 2016. The poor performance of the sector is also reflected in the growth rate over the same period. The poor performance can be attributed to factors such as explosive exchange rate, a fall in the oil price, and disruption of activities within the Niger-Delta by militants (Odularu, 2008; Akinlo, 2012). 
Figure 12: Crude Oil \& Solid Minerals Contribution to GDP(\%)

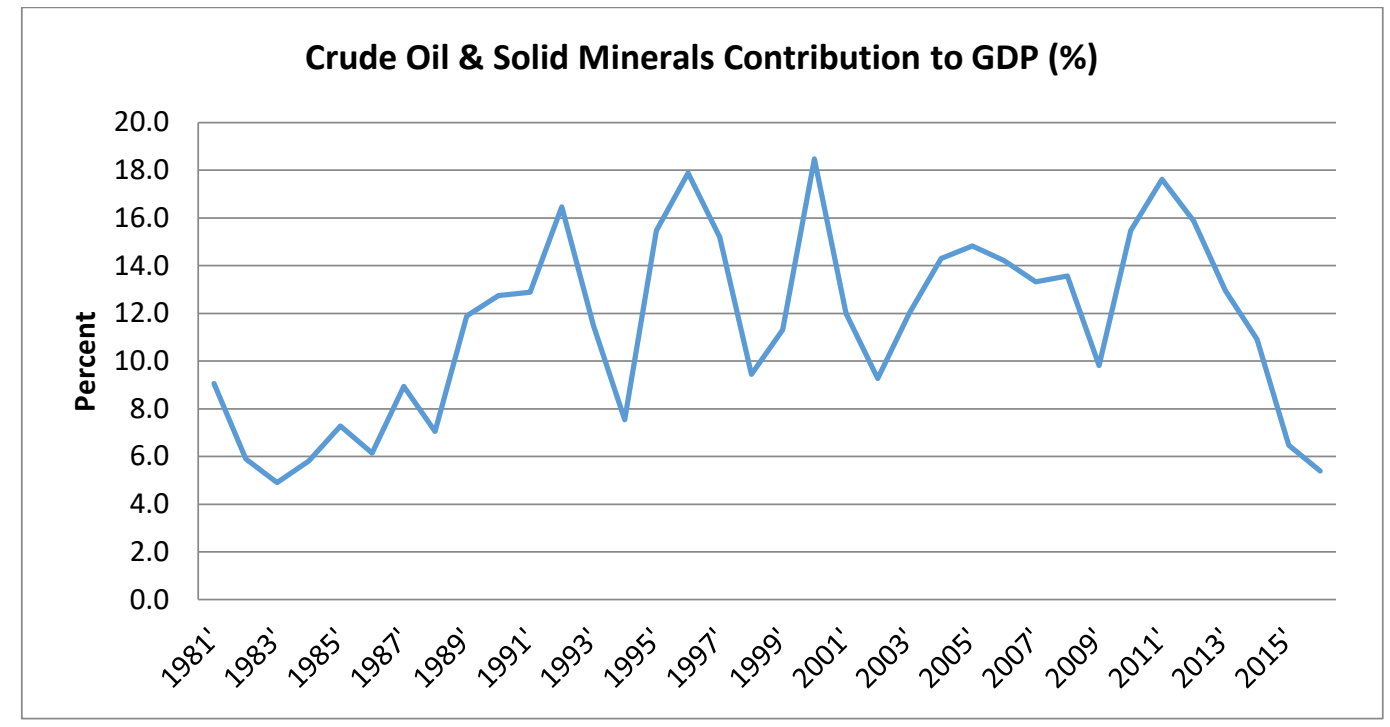

Source: CBN Statistical Bulletin, 2016

Figure 13: Crude Oil \& Solid Minerals GDP Growth Rate (\%)

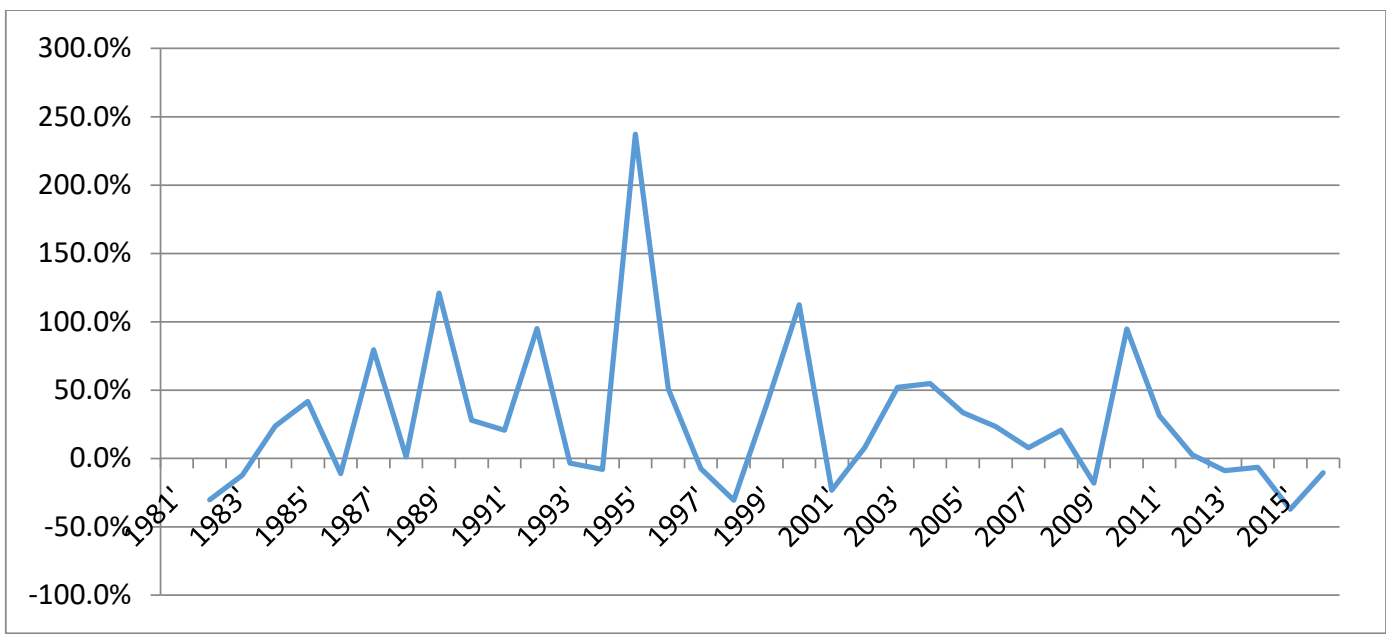

Source: CBN Statistical Bulletin, 2016

\subsection{Manufacturing}

Prior to the GDP rebasing of 2013, Nigeria manufacturing sector consist of Oil Refining, Cement and Other Manufacturing. The sectoral data has since then been expanded and now capture Oil Refining, Cement, Food, Beverage and Tobacco, Textile, Apparel and Footwear, Wood and Wood Products, Pulp, Paper and Paper Products, Chemical and Pharmaceutical Products as well as Non-Metallic Products. 
The manufacturing sector plays an accelerating role in a modern economy and has many dynamic benefits that are crucial for economic transformation. It has the tendency to increase productivity in relation to import substitution and export expansion, bring in foreign exchange earnings, raise employment and promote faster growth (Fakiyesi, 2005). In Nigeria this has not been the case. it has had minimal contribution to the national output and export for decades due to lack of infrastructural support, high interest rates on loan facilities, low quality output, reliance on foreign inputs, overly reliance on oil and policy instability. The dependence on crude oil and neglect of the other sectors which exposed the economy to external shock, unstable government revenue inflow and foreign exchange shortage also retarded the sector.

The distortion of the foreign exchange market (moving from fixed to flexible exchange rate regime) resulting from the structural adjustment programme (SAP) of 1986 marked the beginning of the uncertainty in the manufacturing sector. Since the introduction of second tier foreign exchange market (SFEM) in 1986, the naira has been on a downward spiral (leading to about $49.7 \%$ in devaluation by 1987). This caused a downward slide in the contribution of the manufacturing sector to total economic output in Nigeria in the late 80s (NBS 2014), which is partly due to the overly dependent of the sector on the external sector for import of non-labour input (Okigbo, 1993). The authority responded by merging the first and second tier markets into an enlarged foreign exchange market (FEM) in 1987 and introducing the Interbank foreign exchange market (IFEM) in January 1987 yet, the market remained unstable. Although there were spikes of growth in the sector in 1985,1988, 1993, they were never sustained. They were short-lived due to inadequate availability of foreign exchange. With the rebasing of the GDP data in 2014, the manufacturing sector has shown a slight progressive trend, but still has an average of 46.6 per cent capacity utilisation from 2003 to 2013. As recession set in 2015 to 2016, the exchange rate policy become more unstable, The central bank set limits on foreign exchange allocations; about 41 items (some crucial to the manufacturing sector as inputs) were excluded from the official forex window. Some of these directly affected the manufacturing sector, since about 60 per cent of raw materials for manufacturing are imported.

In the mining and quarrying sector, economic potentials have not been fully harnessed. The fortunes of solid minerals declined significantly following the rising profile of crude petroleum in the 1970s. Mining sites were abandoned as crude petroleum provided cheaper source of energy and government revenue. Consequently, infrastructure at the mining sites deteriorated due to neglect. The potentials of solid minerals therefore remained largely underdeveloped, which compelled the manufacturing sub-sector to depend on importation of minerals that otherwise, would have been produced locally. 
Figure 14: Manufacturing Sector GDP Growth Rate (\%)

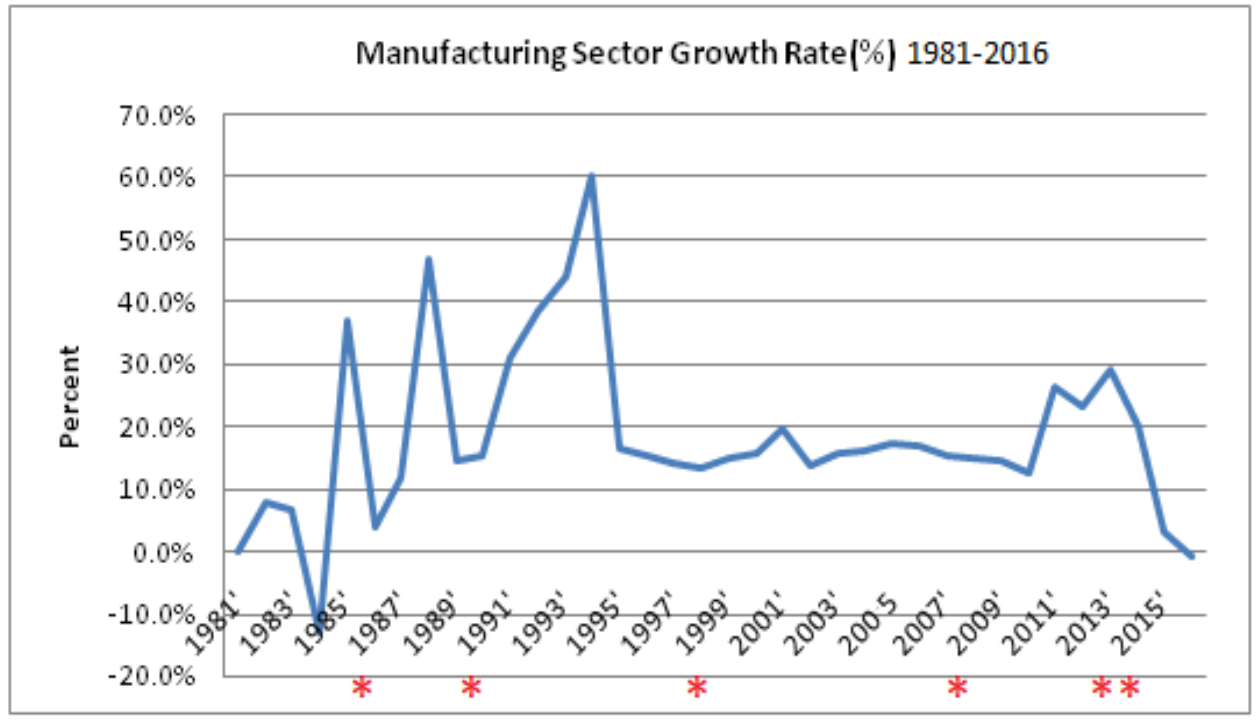

* Devaluation of Naira as Oil Price crashes

Source: CBN Statistical Bulletin, 2016

\subsection{Construction}

To achieve national and economic development, the role of the construction section cannot be overemphasized (Adeagbo, 2014). The sector activities comprise of residential and non-residential construction. The sector is directly related to the level of income in an economy. When the economy is booming, construction activities will be on the rise and vice versa.

From Figure 2.14, it is seen that the over the period of 1981 to 1996, the contribution of the sector to the total output was on the declining path. Thus, during this period the economy was badly affected by the crash in world oil price. Specifically, it declined from $7.6 \%$ in 1981 to $3.2 \%$ in 1985 and then declined further to $1.7 \%$ in 1996 and before stabilizing around 1.9\% between 1997 and 2006. Periods after 2007, it was observed that the contribution of the construction sector to the total output increased with the passage of time till 2015 before declining slightly in 2016. These periods coincide with the economy recorded impressive average growth rate of $6 \%$.

Although the sector inputs are imported and should be adversely affected by the exchanges in the exchange rate, the pattern of the sector performance revealed that the sector is least affect by exchange rate compared to what was observed in the agricultural sector, the manufacturing sector and the crude oil and solid minerals sector. This might be because the activities carried out involve the rendering of services that support other sectors of the economy. Thus, the sector activities rely on 
the country economy outcome. A clear evidence of this is the growth rate of the sector output during the harsh economic periods of 1981 to 1986, although, on average, the sector recorded a positive growth rate. The implication of this is that over the period of 1987 till 2016 as depicted in Figure 9, the sector output has been growing.

Figure 15:Manufacturing Sector Contribution to GDP (\%)

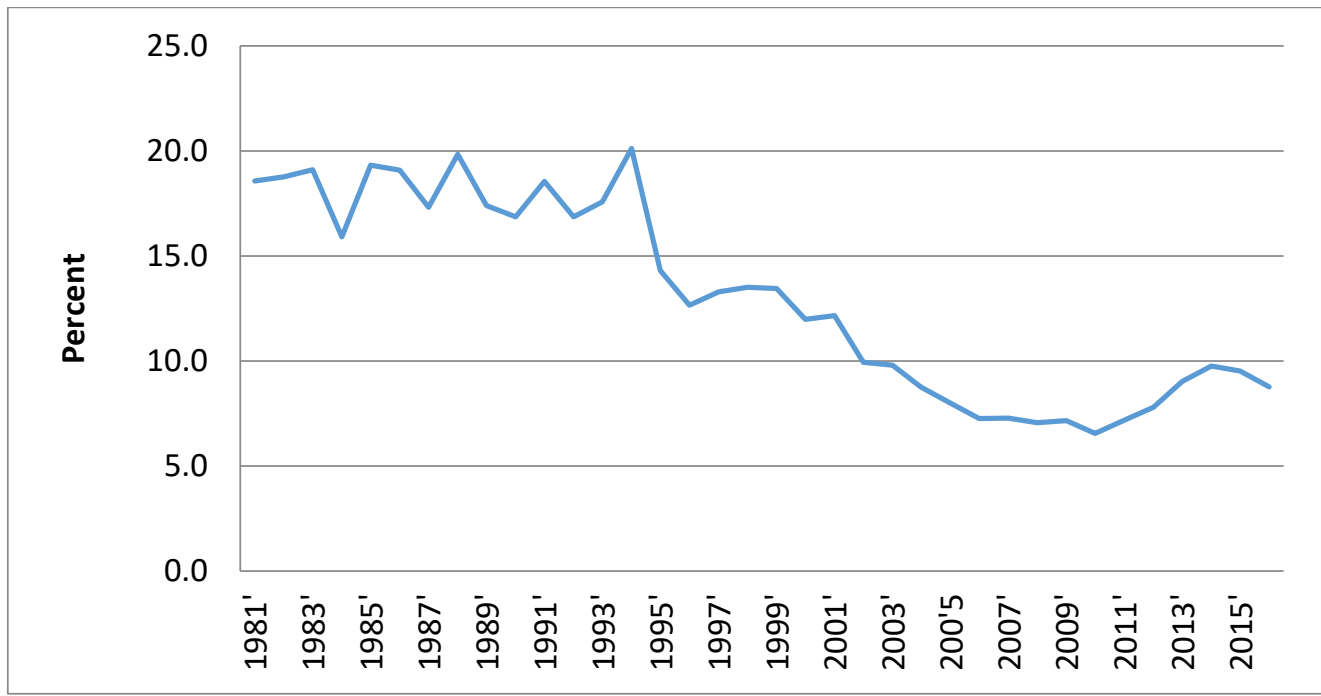

Source: CBN Statistical Bulletin, 2016.

Figure 16: Construction Sector contribution to GDP (\%)

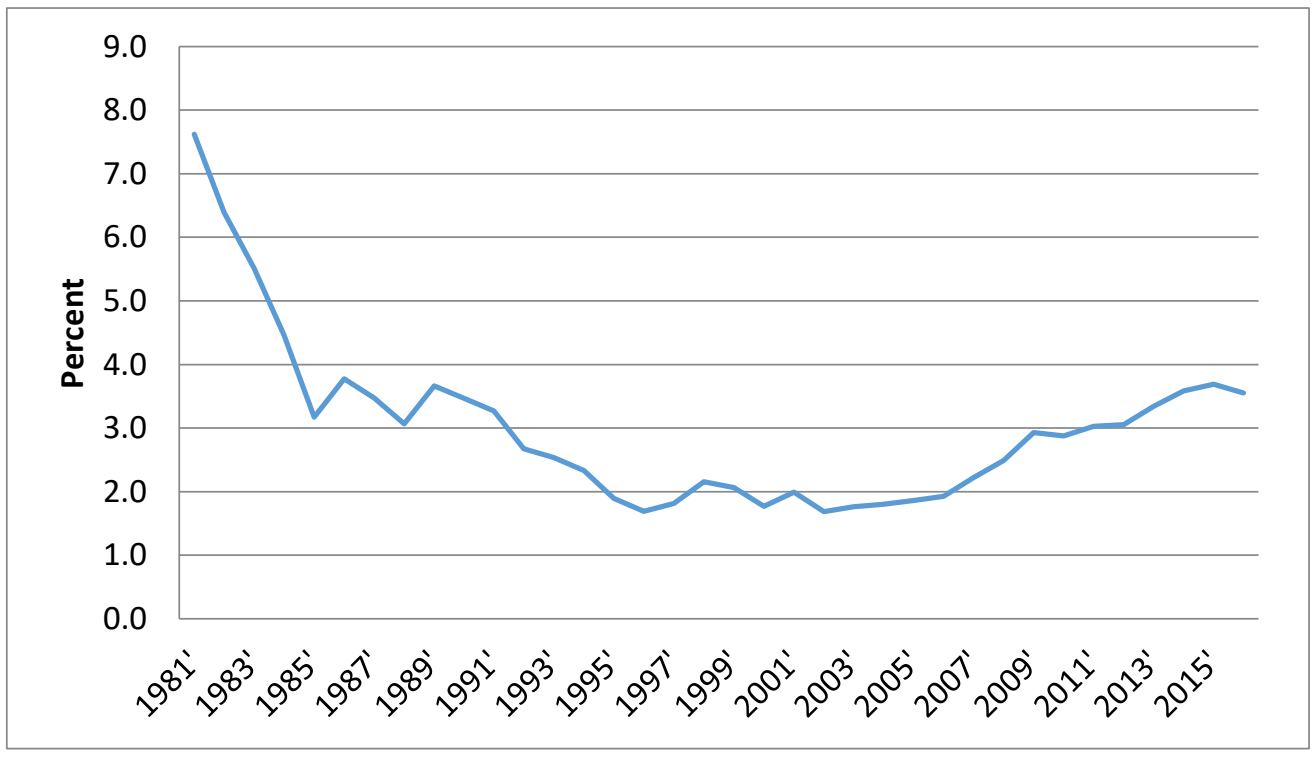

Source: CBN Statistical Bulletin, 2016. 
Figure 2.17: Construction Sector Growth Rate (\%)

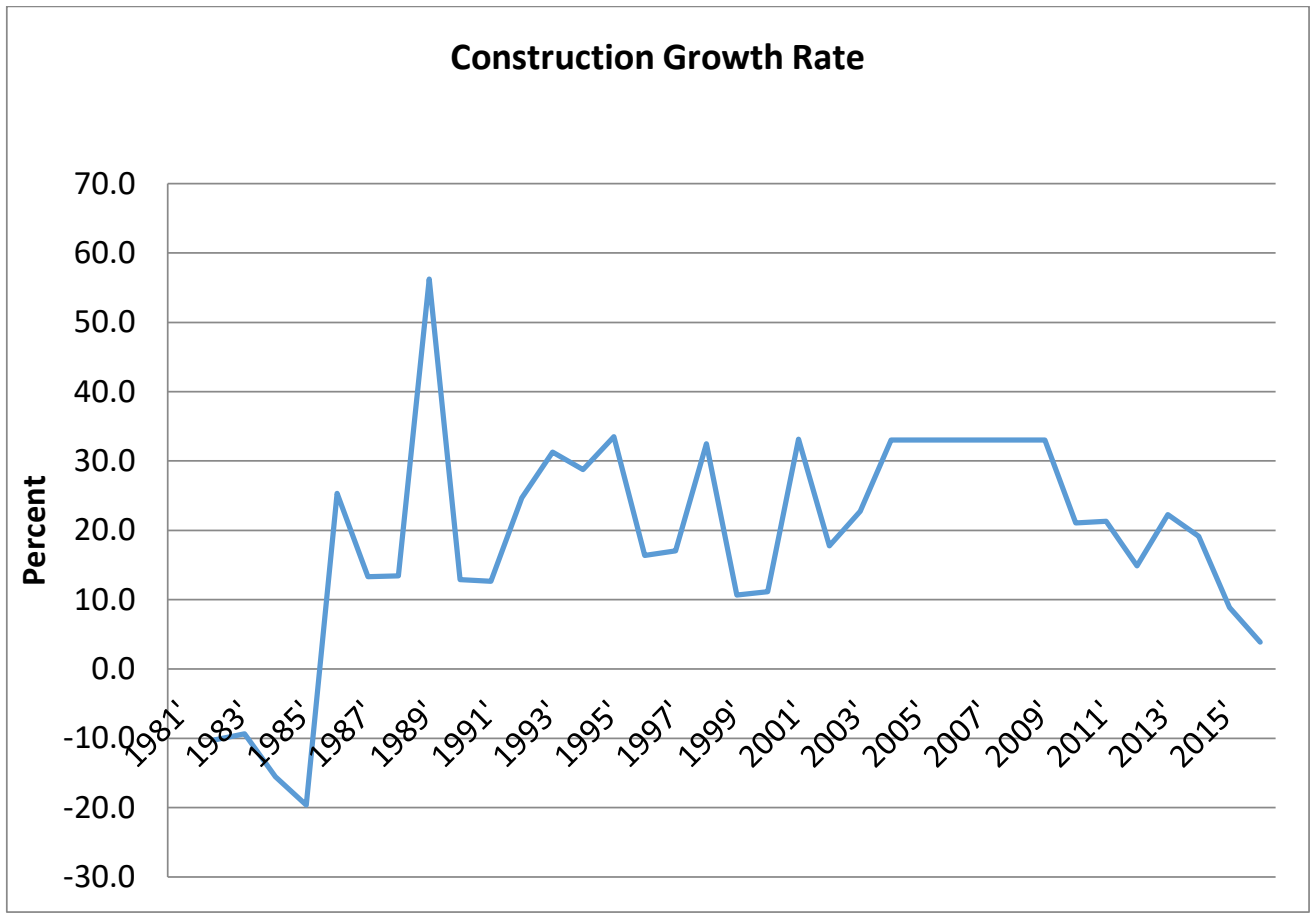

Source: CBN Statistical Bulletin, 2016

\subsubsection{Trends in the Services Sector in Nigeria}

The constituents of services sector in Nigeria include Trade, Information and Communication, Real Estate, Public Administration, Professional, Scientific and Technical Services and Financial Institutions The services sector has emerged as a dynamic sector whose importance has continued to rise in terms of growth rate and contribution to GDP. Over the years, the growth rate of the sector has been positive and from 1981 to 1988, it was around 7.86 per cent on average before it rose sharply to 43.75 per cent in 1989 (Figure 2.11). It fell in 1990 to as low as 3.01 per cent before it picked up the following year and witnessed a steady growth from 1991 to 1994, where it had the highest growth rate of 51.26 per cent (Figure 2.19). The high growth was largely attributable to improvement in transportation services. the establishment of the mass transit system that year and the increased flow of people and goods resulting in enhanced productivity. (Oyejide and Bankole, 2001). Another stability was witnessed between 1996 and 2003 as the rate oscillated around 20 per cent during the period. There was an upward trend between 2003 and 2006 owing to the expansion in telecommunication services. The introduction of the Global system of Mobile Communication in Nigeria in 2001. Telecommunication did not only lead to increase in the tele- density, it also led to improvement in the productivity of other 
services. Growth in the sector stabilised at an average growth of 13.29 per cent from 2007 to 2013.

Figure 2.18: Services Sector Growth (\%)

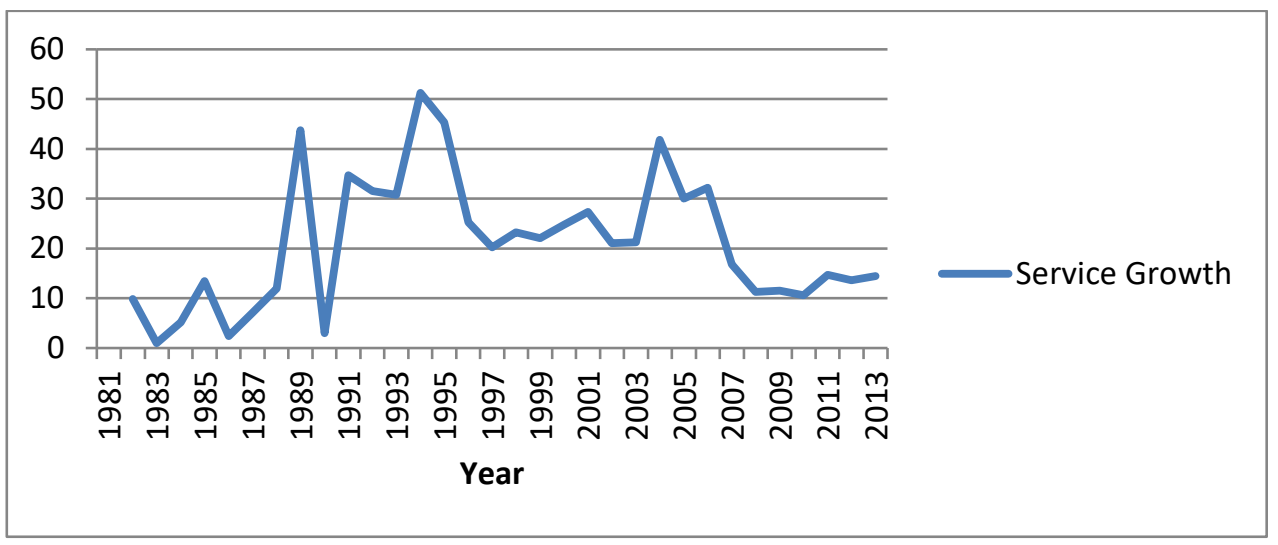

Figure 2.19: Trade Sector Contribution to GDP (\%)

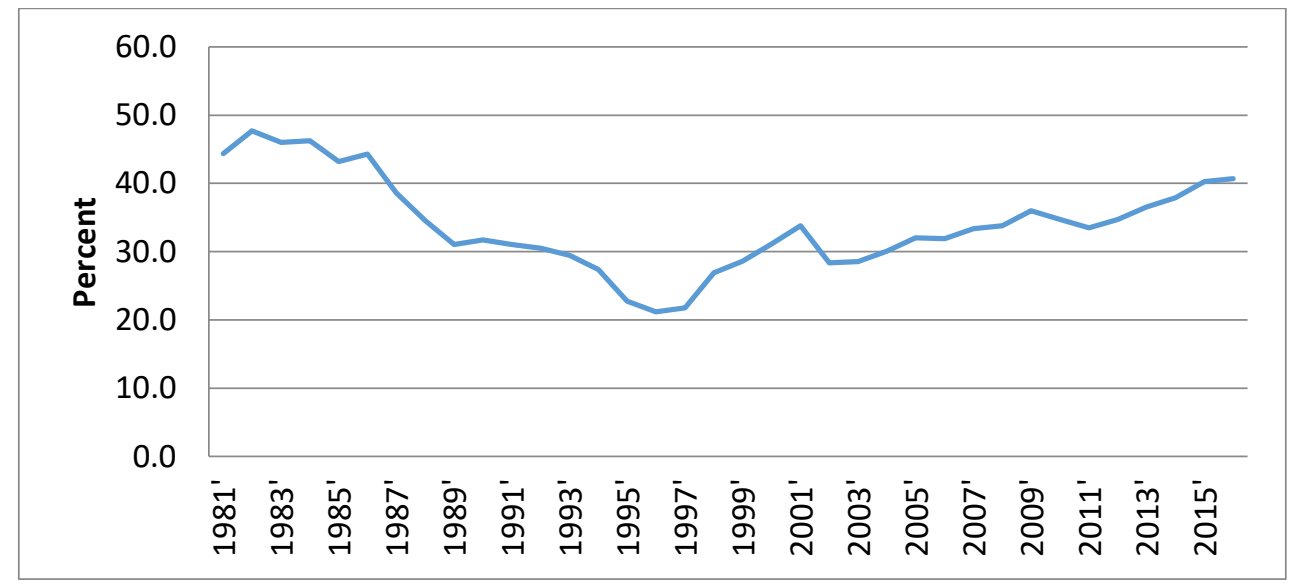

Figure 2.21: Trade Sector GDP Growth Rate (\%)

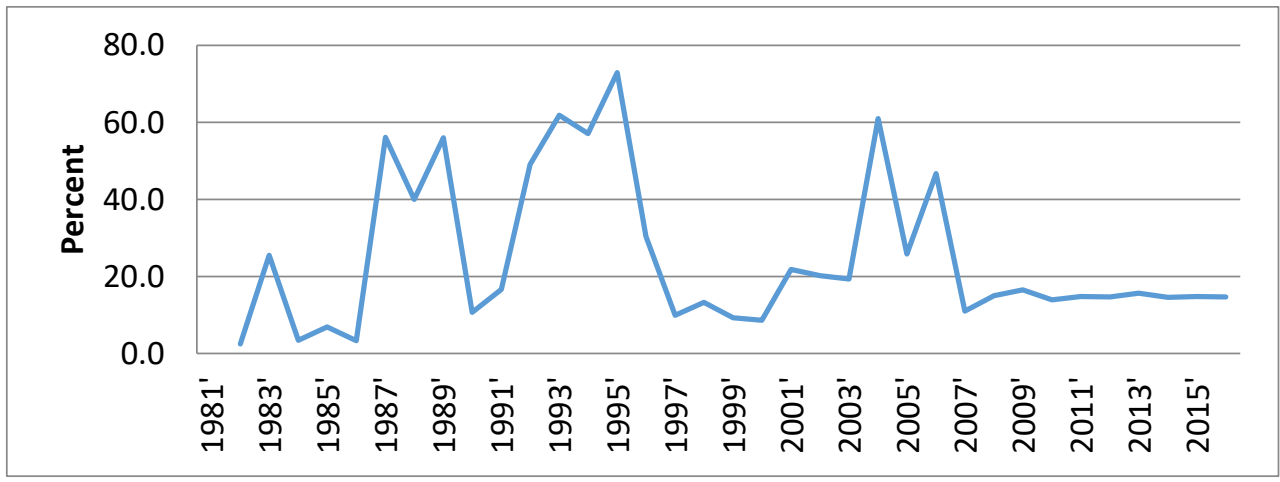


Tourism is not left out in the poor performance syndrome that has continued to characterise the real sector of the economy. Although it has strong potentials for enhancing employment and revenue for the country, such potentials have remained largely underdeveloped. Employment and revenue from tourism have remained low and insignificant while foreign exchange earnings have been virtually nonexistent. The factors responsible for this performance include poor and inadequate infrastructure, political instability, social insecurity, and failure of government to create enabling environment for private sector participation in the industry.

The Nigerian health sector is characterised by brain drain as experienced Nigerian health experts are migrating to other countries in search of better conditions of service. This has led to deterioration of the country's healthcare system. There is high infant and maternal mortality rate as well as the prevalence of diseases in epidemic proportions. Massive immunisation against all vaccine preventable diseases was embarked on by the government to address the issues. Other steps taken by the government include ensuring universal access to primary healthcare, eradication and prevention of epidemic diseases, resuscitating the secondary healthcare system and stepping up enlightenment campaign on HIV/AIDS pandemic. To stem the migration of health workers, the salaries of the health experts were reviewed upward and condition of service was also improved to make working in Nigeria attractive.

\subsection{Structure and Behaviour of Labour Supply in Nigeria}

The structure of labour supply reflects colonial and cultural antecedents as well as social norms prevailing in the country. Considering the profile of the labour force, the population distribution showed that majority of the population were within the age bracket, 15 to 65 years in 2013. This represents about 52.9 per cent, only 2.5 per cent are above 65 years. The labour participation rate is low. Just about 38 per cent and 52 per cent are for female and male respectively in 2013. Of the employment population, agriculture accounts for 60 per cent and it is usually in small holding farming. The industry accounts for less than 6 per cent, service for 17 per cent and agriculture for 41 per cent of the total working population distribution in Nigeria.

Also, the informal sector is the largest employer of labour. Most people within the working age bracket are either engaged as proprietors, paid employees, unpaid family workers or apprentices. Official estimate of those seeking job but unable to find is about 7.5 per cent of the labour force. The prevalence of informal sector is common to the rural and urban settings. The dominance of the informal sector in the urban centre is quite strong while informal agriculture predominates in the rural areas. Therefore, close to 90 per cent of the agricultural activities are carried out at subsistent level in the rural areas. The largest share of employment in the formal sector is provided by the government; this has led to ballooning of the public sector payroll (Agbodike et al, 2015). 


\subsubsection{Labour Supply and Unemployment in the Real Sector in Nigeria}

The spate of unemployment in Nigeria is very high. Data on sectoral unemployment is hard to find in Nigeria. Since unemployment and employment are mirror image, whether unemployment rate is increasing or decreasing in one sector can be viewed by looking at the employment rate in the various sectors. Nigeria's economy can broadly be classified into three major sectors, namely primary (Agriculture and natural resources); secondary (mainly Industry) and Tertiary (services as well as wholesale and retail trade) (CBN, 2003). Agriculture is predominant in the primary sector. Agriculture is predominant in the primary sector of the Nigerian economy. Therefore, this section gives the trend analysis of employment rate in the primary and secondary sectors using agriculture and industry, respectively.

\section{Figure 2.22 Employment in the Agricultural and Manufacturing Sectors in Nigeria}

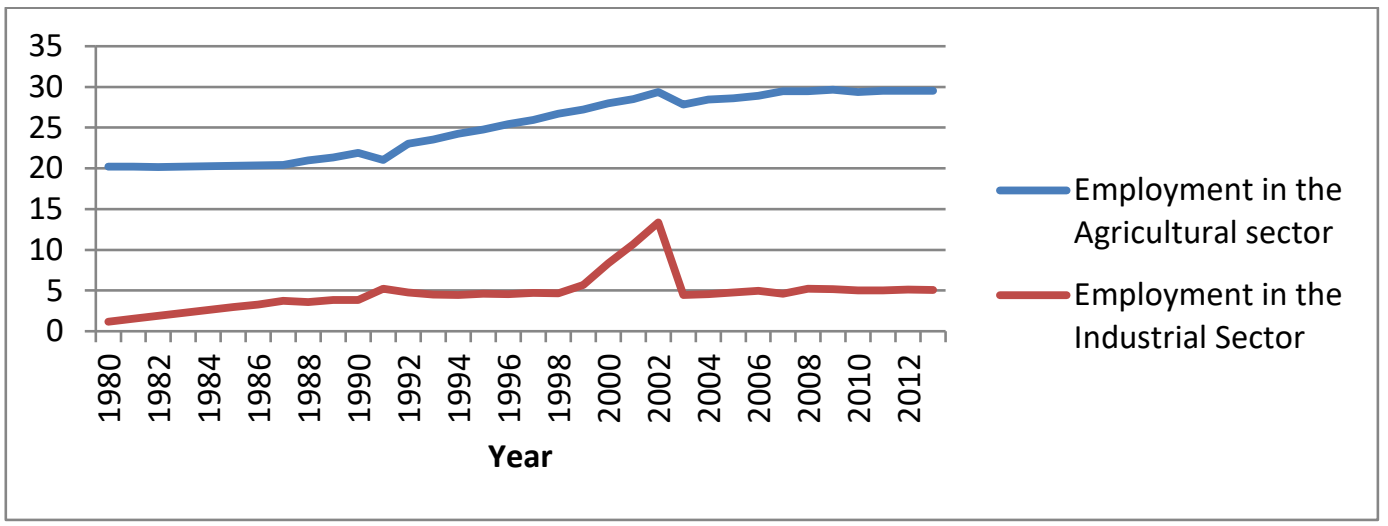

Source: National Bureau of Statistics (2013)

Over the years, the employment rate in agriculture trends upwards and remained the largest employer of labour in the country (Figure 2.12). The reason is because the system of agriculture practiced in Nigeria is still rudimentary and largely labour intensive. Between 1980 and 1987, the rate of employment in agriculture was approximately 20 per cent. Apart from the marginal fall in 1991 and 2005, there has been steady increase in the rate on an average of 1 per cent every year.

For the industry, the employment rate has been very low over the years apart from the major increase of 10.67 per cent and 13.36 per cent in 2001 and 2002 respectively. The employment rate in the industrial sector on the average is approximately four per cent. This is very low compared with other sectors. Manufacturing activities have been on the decline owing to the non-competitiveness of the sector. Poor infrastructure and inconsistencies in government policies have seen several manufacturing concerns close discontinue their operations. 


\subsubsection{Labour Supply and Employment in the Services Sector in Nigeria}

In recent times, the Nigerian economy can be service-led due to structural transformation taking place in the economy (Alemu, 2015). From Figure 2.13, the employment rate in the service sector was very low between 1980 and 2002 as its value was below one per cent. The major increase started in 2003 when the employment rate in the sector jumped from a low value of 2.1 per cent in 2002 to a high value of 14.5 per cent in 2003 . Ever since, there has been a steady increase in the employment rate in the sector. The growth of the service sector can be traced to economic development of Nigeria and the sociocultural changes that have accompanied those environmental forces separately or in combination that created new type of services. It was also revealed that satisfaction of customers' demand, extension of product range, dealing with new competitors at home, improvement of product quality, compliance with Nigeria laws and standards as well as dealing with the challenges of new technology underlined very important motivating factors (Adewole et al., 2012).

\section{Figure 2.23 Employment in the Services Sector}

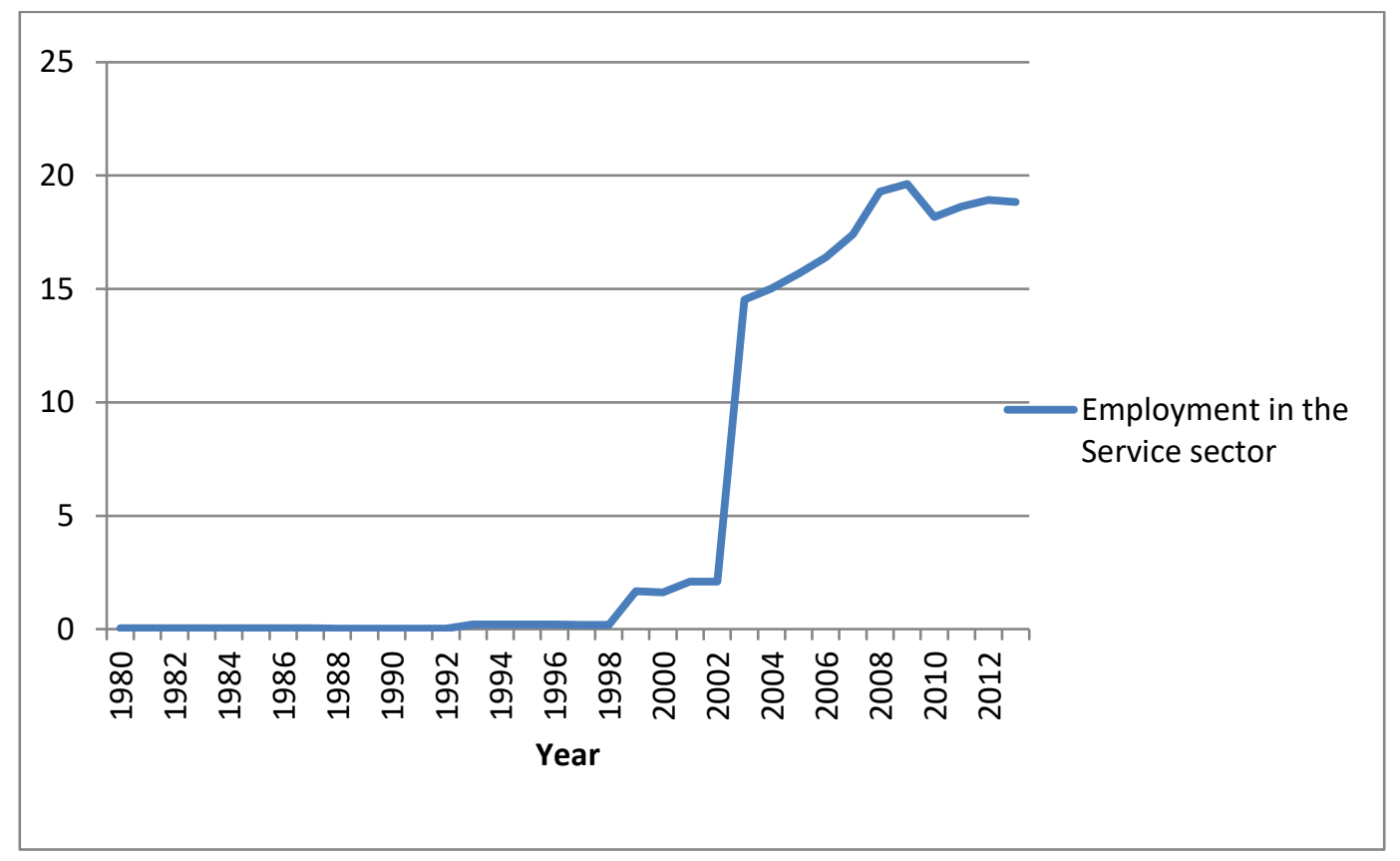

Source: National Bureau of Statistics (2013)

\section{Conclusion}

This paper examined the sectoral performance and unemployment in the Nigerian economy. The Nigerian macroeconomic structure is complex and comprises interrelated sectors and activities. The performance of the various sectors was not 
impressive despite its high potential for achieving a far-reaching and diversified economy. The spate of unemployment is also very high though the employment level in various sectors increased over the year. This depicts that the growth rate in employment did not catch up with the number of people that joined the Nigerian labour force.

\section{References}

[1] Adeagbo, A. (2014). Overview of the building and contruction sector in the Nigerian economy. JORIND, 12(2), 349-366.

[2] Akinlo, A. E. (2012). How important is oil in Nigeria's economic growth? Journal of Sustainable Development, 5(4), 165-179.

[3] Chidozie, F. C., Olanrewaju, I. P., \& Akande, O. O. (2014). E-ISSN 2039-2117 ISSN 2039-9340 Mediterranean Journal of Social SciencesMCSER Publishing, Rome-ItalyForeign Megastores and the Nigerian Economy: A Study of Shoprite. Mediterranean Journal of Social Sciences , 5 (1).

[4] David, O., Umeh, J. C., \& Ameh, A. A. (2010). The effect of exchange rate fluctuations on the Nigerian manufacturing sector. African Journal of Business Management, 5.

[5] Fadason, R., Danladi, C., \& Jatau, S. (2017). Construction Standard and Regulation in Nigeria. Surveying the world of tomorrow - From digitalisation to augmented reality, (p. 15). Helsinki, Finland.

[6] Federal Ministry of Agriculture and Rural Development. (2000). Nigeria: Agricultural and rural transformation programme - Vision to action.

[7] Gatawa, N. M., \& Mahmud, A. A. (2017). Impact of Exchange Rate Fluctuations on Agricultural Exports (Crops) In Nigeria. International Journal of Humanities and Social Science Invention , 6 (3), 7.

[8] ILO. (2012, December 12). ILO Newsroom. Retrieved January 17, 2018, from http://www.ilo.org/global/about-theilo/newsroom/features/WCMS_195532/lang--en/index.htm

[9] Isa, R. B., Jimoh, R. A., \& Achuenu, E. (2013). An overview of the contribution of construction sectorto sustainable development in Nigeria. Net Journal of Business Management , 1 (1), 6.

[10] Mmaduabuchukwu, M. (2003). Service Trade and Non-oil export in Nigeria. Journal of Business Administration and Education , 2 (2), 18.

[11] NBS. (2014). Nigerian Manufacturing Sector: SUMMARY REPORT 2010-2012. National Bureau of Statistics.

[12] Obayelu, A. E., \& Salau, A. S. (2010). Agricultural Response to Prices and Exchange Rate in Nigeria:Application of Co-integration and Vector Error Correction Model(VECM). Journal of Agric Science, , 9.

[13] Odularu, G. O. (2008). Crude oil and the Nigerian economic performance. Oil and Gas Business, 1-29. 
[14] Ogundipe, O. M., Ojeaga, P., \& Ogundipe, A. A. (2014). Oil Price and Exchange Rate Volatility in Nigeria. IOSR Journal of Economics and Finance (IOSR-JEF), $5(4), 9$.

[15] Olufayo, M. B., \& Fagite, B. A. (2014). Exchange Rate Volatility and Sectoral Export of Nigeria: Case of Oil and Non-Oil Sectors. Journal of Economics and Sustainable Development, 5 (10).

[16] Onwe, B. U. (2015). Implications Of Exchange Rate Variability On Oil Exports Trade Performance In Nigeria. Global Advanced Research Journal of Management and Business Studies , 4 (11), 461-468.

[17] Philip Consulting, (2014). A study of current trends in online shopping in Nigeria. Lagos: PCL Business Advisory Division.

[18] Rewane, B. (2016, February 11). Reports. Retrieved January 11, 2018, from Proshare:

https://www.proshareng.com/admin/upload/reports/DebateExchang.pdf

[19] Sertoğlu, K., Ugural, S., \& Bekun, F. V. (2017). The Contribution of Agricultural Sector on Economic Growth of Nigeria. International Journal of Economics and Financial Issues, 6.

[20] Wahab, L. A. (2011). An analysis of government spending on agricultural sector and its contribution to GDP in Nigeria. International Journal of Business and Social Science, 2(20), 244-250. 